\title{
Environmental Effects on Fortified Palm Olein in the Anthropocene
}

\author{
Adia Nuraga Galih Pradipta, Sukmo Wening Andayani, Dewi Yuliyanti, Latifun Jayanti, Dewi \\ Kristina Natalia Silalahi, Isti Christianti, Karyanto Mulyono \& Paul Wassell* \\ E-mail: paul.wassell@sinarmas-agri.com
}

Golden Agri-Resources (GAR), R\&D, Marunda center, Tarumajaya, Jawa Barat, 17211, Indonesia

\begin{abstract}
Until now, no literature exists to explain about the impact of time, and environmental parameters, when using typical commercial grade transparent linear low density polyethylene (LLDPE) packaging for protecting vegetable cooking oil during typical shelf-life conditions. We tested long-term impact of temperature and illuminance (light: 100 to 150 lux and darkness $<1$ lux) on refined bleached deodorized palm olein (RBDPOL), fortified with vitamin A. Results showed degradation of fortified RBDPOL with 70 ppm vitamin A was approximately $15 \%$ at $18-22^{\circ} \mathrm{C}$ in Light, $10 \%$ at $18-22^{\circ} \mathrm{C}$ in Darkness, $19 \%$ at $32-33^{\circ} \mathrm{C}$ in light and $17 \% 32-33{ }^{\circ} \mathrm{C}$ in darkness. Similar trend was observed at $45 \mathrm{ppm}$ vitamin A. Exposure to heat and light impacted vitamin A degradation, but is primarily attributed to temperature, irrespective of packaging. This investigation builds on our previous work (Silalahi et al., 2017), and confirms the impact of challenging environmental conditions on vegetable cooking oil shelf-life over long time periods.
\end{abstract}

Key words --- Vitamin A, Shelf-life, Illuminance, Stability, Fortified Palm, Packaging,

\section{INTRODUCTION}

Providing sustainable food in the Anthropocene is never more urgent. Many environmental systems and processes are pressed because food production is not operating efficiently. Achieving healthy sustainable food systems will require large reductions in food loss and waste, together with improved food production practices [1]. Within this context, from 2012, several nations adopted fortification policies to include vegetable oil as a fortified delivery mechanism [2, 3]. More recently, one global supplier of palm oil, has also opted to fortify palm based vegetable cooking oil with vitamin $\mathrm{A}[4,5]$.

Edible oil fortification, is a potentially useful means of expanding the present reach of vitamin A [6] But, stability is shown to be problematic in some environments $[7,5]$. Factors such as acidity, moisture, ultraviolet light, oxygen and heat are well established causes [8 -12]. Clearly, given new global challenges of delivering sustainable food systems in the Anthropocene, attention should also be considered, not only for the food system itself, but also for the total delivery mechanism, naturally comprising materials used to protect the food system [1]. Without doubt, there is still continued interest to establish the most ideal methods for determining the most suitable environmental conditions and packaging materials [13] for long-term vitamin stabilisation [14, 15]. A recent study [1], noted several effects from choice of packaging material, to protect vitamin A and noted beneficial effects of Polyethylene Terepthalate (PET) vs transparent nylon, possibly attributed to improved gas transmission rates and water vapour permeability. The same study showed that opaque Nylon enabled better vitamin A retention, compared to transparent PET, because vitamin A is known to be more sensitive to UV light [16]. than oxygen attack $[17,18]$.

Although, others [5] previously considered the effects of differing packaging materials on vitamin A degradation, the experimental design did not clearly show the effect of illuminance (lux). Based on these aforementioned factors, no literature exists to explain the effect of illuminance on fortified vegetable oil using commercial packaging materials during typical environmental shelf-life conditions. Therefore, this study aims to establish this effect at several isothermal conditions using commercial food grade packaging.

As in previous studies, Refined Bleached Deodorised Palm Olein (RBDPOL) was used and preferred for its good oxidative stability $[19,5]$.

\section{MATERIALS AND METHOD}

\section{A. RBDPOL}

Supplied from PT. SMART, Tbk, Indonesia. Key parameters are described in Table 1. Vitamin A 1.0 mio IU, was supplied from DSM Nutritional Products Ltd., Singapore (Table 2).

TABLE 1.

Refined Bleached DeOdorized Palm Olein (RBDPOL)

\begin{tabular}{lcc}
\hline $\begin{array}{c}\text { Analysis } \\
\text { Parameter }\end{array}$ & Method & Result \\
\hline Iodine Value & AOCS Cd 1b-87 & $60.67 \pm 0.15$ \\
\hline Peroxide Value & AOCS Cd 8-53 & $0.5 \pm 0.02$ \\
\hline Free Fatty Acid & AOCS Ca 5a-40 & $0.04 \pm 0.00$ \\
\hline Moist \& impurities & AOCS Ca 2b-38 & $0.05 \pm 0.01$ \\
\hline Color & AOCS Cc 13e-92 & $2.2 \pm 0.01$ \\
\hline
\end{tabular}

TABLE 2.

DESCRIPTION OF ESSENTIAL Parameters of Vitamin A Assay

Parameter Specification

\begin{tabular}{ll}
\hline Peroxide Value, meq $\mathrm{kg}^{-1}$ & Max. 10.0 \\
\hline Acid value, mg KOH g & \\
\hline
\end{tabular}


B. Iodine Value (IV), Peroxide value (PV), Free fatty acid (FFA), Moisture \& Impurities (M\&I), Colour measurement determination

The iodine value was determined by iodometric titration (AOCS Ca 1b-87). Peroxide value was determined by AOCS Cd 8-53, 2009. Free fatty acids were determined by AOCS $\mathrm{Ca} 5 \mathrm{a}-40$. Moisture was determined by AOCS Official Method Ca 2b-38. Oil colour was determined by Lovibond Tintometer colour scale (AOCS Cc13e-92).

\section{Storage conditions and sampling}

Oil samples were prepared in typical laboratory conditions, then stored with or without light exposure, at two temperature ranges; first $18-22^{\circ} \mathrm{C}$ [20], representing typical air-conditioned supermarket and second $32-33^{\circ} \mathrm{C}$ [21] representing non-temperature control storage (Table 3). Light measurement (illuminance), was quantified using a Digital Lux Meter LX1010B (supplied by Mextech, India). Lux, being equal to one lumen per square metre $(1 \mathrm{~lx}=1$ $1 \mathrm{~m} / \mathrm{m}^{2}$ ). The JIS C 1609-1 standard [22, 23] defines performance requirements for illuminometers. In this study darkness is defined as $<1$ Lux. Illuminance (light) $=100$ to 150 Lux.

TABLE 3.

STORAGE CONDITIONS FOR FORTIFIED (VITAMIN A) RBDPOL

\begin{tabular}{ccc}
\hline \multirow{2}{*}{$\begin{array}{c}\text { Fortification Dosage } \\
\text { Vitamin A }\end{array}$} & \multicolumn{2}{c}{ Storage Condition } \\
\cline { 2 - 3 } & $\mathbf{1 8 - 2 2}^{\mathbf{}} \mathbf{C}^{*}$ & $\mathbf{3 2 - 3 3}^{\mathbf{0}} \mathbf{C}^{* *}$ \\
\hline \multirow{2}{*}{$45 \mathrm{ppm}$} & Light & Light \\
\cline { 2 - 3 } $70 \mathrm{ppm}$ & Dark & Dark \\
\cline { 2 - 3 } & Light & Light \\
\hline
\end{tabular}

*Storage $18-22^{\circ} \mathrm{C}$ represents air-conditioned supermarket (Howell, 1997)

** Storage $32-33^{\circ} \mathrm{C}$ represents non-temperature control (BMKG Jakarta 1981-2010)

Dark Condition : illumination 0 Lux

Light Condition : illumination 100-150 Lux (warehouse, CIBSE

Recommendation 2012)

Preparations of RBDPOL and vitamin A 1.0 mio IU (retinyl palmitate) were assembled at concentrations of 70 IU g-1 and 45 IU g-1, described previously [24, 5] and studied in $225 \mathrm{ml}$ transparent nylon LLDPE (linear low density polyethylene) pouch supplied from Panverta, Indonesia. (Specification Nylon $15 \mu /$ adhesive / LLDPE $120 \mu)$.

\section{Quantification of vitamin $A$ by high performance liquid chromatography (HPLC)}

The vitamin A was determined by liquid chromatography method [25]. Standardized vitamin A (Retinyl palmitate) was supplied from Supelco-Sigma Aldrich (purity 93.8\%).

HPLC determination was started with baseline check for a minimum of 30 minutes with mobile phase methanol: ultrapure water (95:5) at flow rate $0.5 \mathrm{~mL} / \mathrm{min}$. Instrument: Shimadzu Prominence-i LC-2030 C. Column: Shim Pack GIST C18 4.6 x $150 \mathrm{~mm}$. Mobile phase: methanol: ultrapure water (95:5). Flow rate: $0.5 \mathrm{~mL} / \mathrm{min}$.
Vol. Inject: $10 \mu \mathrm{L}$. Detector: UV. Wavelength: $328 \mathrm{~nm}$. Calculation: Determination of vitamin A in sample using calibration.

$$
y=b x+a ; \quad x=\frac{(y-a) / b}{\text { weigh of sample }(g)}
$$

Where: $y=$ peak area

$$
\begin{aligned}
& b=\text { slope } \\
& a=\text { intercept } \\
& x=\text { Vitamin } A \mathrm{IU} / \mathrm{g} \text { in sample }
\end{aligned}
$$

Calculation of retained vitamin A in RBDPOL in $n$ month was determined by the following:

$$
\frac{C_{n}}{C_{0}} \times 100 \%
$$

$C_{0}=$ vitamin $A$ content: 0 month $(I U / g)$

$C_{n}=$ vitamin A content: $n$ month (IU/g)

\section{E. Statistical analysis}

Statistical analysis was first examined using a combination of Student t-test to determine uncertainty [26]. Final analysis was carried out using analysis of variance $(\alpha$ $=0.05$ ) with MiniTab v.16.1.1 software.

\section{RESULTS AND DISCUSSION}

\section{A. Calibration of Vitamin A}

A calibration of vitamin A level concentration (IU/g) is shown previously in [1]. Calculations show corellation between peak area obtained from analysis using HPLC and regression of linearity.

\section{B. Effect of temperature and illuminance on vitamin $A$ stability}

Figures 1 and 2, show the impact of both temperature and illuminance (light: 100 to 150 lux and darkness $<1$ lux) during storage of fortified RBDPOL with Vitamin A (70 and $45 \mathrm{ppm}$ ). After six (6) months monitoring, the degradation of RBDPOL fortified with $70 \mathrm{ppm}$ vitamin A was approximately $15 \%$ at $18-22^{\circ} \mathrm{C}$ in Light, $10 \%$ at $18-22^{\circ} \mathrm{C}$ in Dark, $19 \%$ at $32-33^{\circ} \mathrm{C}$ in light and $17 \% 32-33^{\circ} \mathrm{C}$ in dark. A similar trend was observed in RBDPOL fortified with 45 ppm vitamin A, after 6 months. The vitamin A degraded by approximately $13 \%$ at $18-22^{\circ} \mathrm{C}$ in light, $13 \%$ at $18-22^{\circ} \mathrm{C}$ in dark, $22 \%$ at $32-33^{\circ} \mathrm{C}$ in light and $16 \% 32-33^{\circ} \mathrm{C}$ in darkness. 


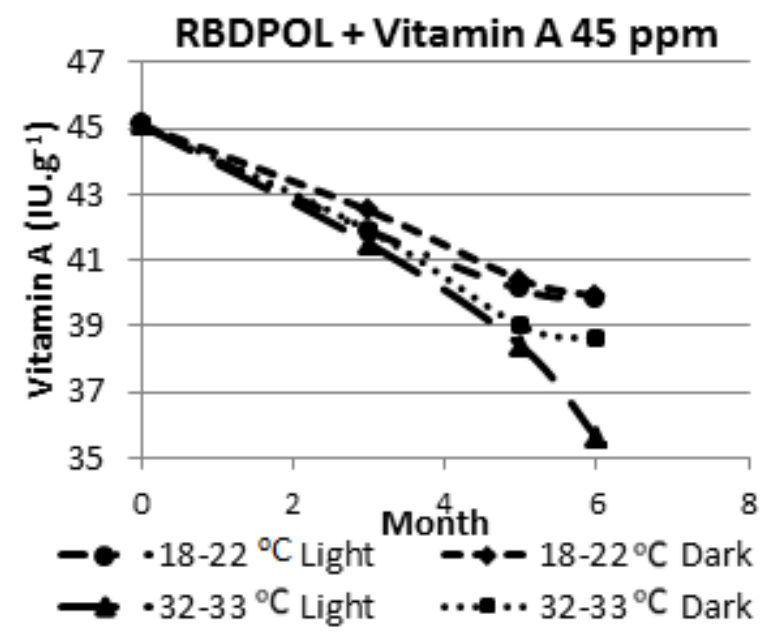

Fig. 1 Impact of temperature and illuminance (light: 100 to 150 lux and darkness $<1$ lux) during storage of fortified RBDPOL (45 ppm vitamin A)

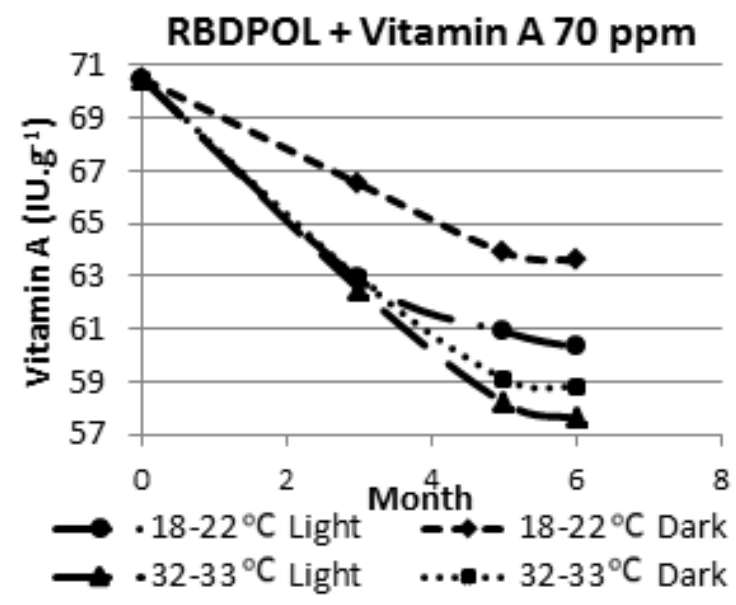

Fig. 2 Impact of temperature and illuminance (light: 100 to 150 lux and darkness $<1$ lux) during storage of fortified RBDPOL (70 ppm vitamin A)

The data also shows the effect of temperature on the degradation of vitamin A during storage. A temperature of $32-33^{\circ} \mathrm{C}$ giving higher Vitamin A degradation versus 18 $22^{\circ} \mathrm{C}$. This result confirms similar findings on temperature impact of vitamin A degradation in [12]. Secondly, although test samples did not have direct exposure to natural sunlight, this observation shows the effect of vitamin A fortified RBDPOL to direct light exposure (100 to 150 lux) or darkness ( $<1$ lux). Light (100 to 150 lux) conditions, will accelerate vitamin A degradation in RBDPOL faster than if $<1$ Lux condition. Exposure of RBDPOL vegetable oil, does have impact on stability of vitamin A [10].

Table 4, shows that temperature storage is probably contributing the biggest impact to degradation of vitamin A. After six (6) months monitoring, all samples stored at 18$22^{\circ} \mathrm{C}$ had vitamin A degradation of approximately $10-15 \%$. Whereas, all samples stored at $32-33^{\circ} \mathrm{C}$ degraded by approximately $16-22 \%$. These data confirm similar findings [5].

\section{Correlation of PV value to vitamin $A$ degradation}

As described previously [5], for vitamin A fortification studies, the peroxide value (PV) was monitored to acceptable level of 10 meq $\mathrm{kg}^{-1}$ [19]. Figures 3 and 4 show the effect of peroxide (PV) to decrease vitamin A. Linearity was observed for $45 \mathrm{ppm}(\mathrm{y}=-0.3106 \mathrm{x}+43.035)$ and $70 \mathrm{ppm}(\mathrm{y}=-0.603 \mathrm{x}+67.149)$. This confirms a similar tendency noted by others for a compound decrease of vitamin $A$ in oxidized oil $[5,27,28]$.

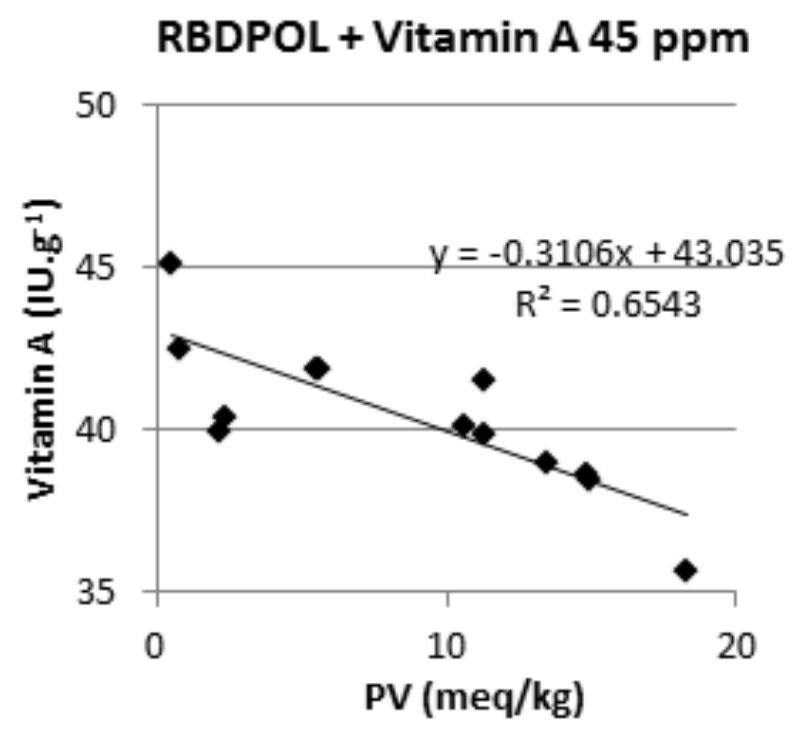

Fig. 3 Effect of PV during storage of fortified RBDPOL (45 ppm vitamin A)

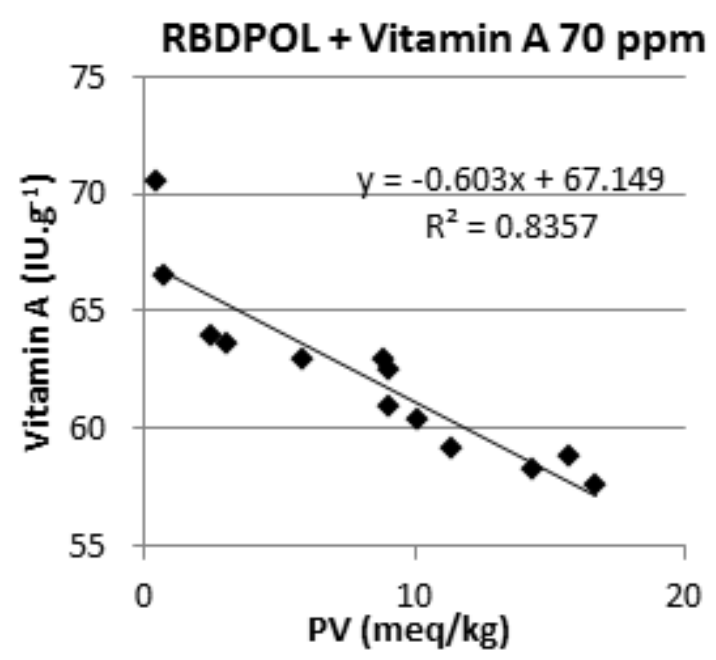

Fig. 4 Effect of PV during storage of fortified RBDPOL (70 ppm vitamin $\mathrm{A}$ ) 
Table 4.

Effect of Lux and temperature on degradation of fortified (vitamin A) RBDPOL

\begin{tabular}{|c|c|c|c|c|c|c|c|c|c|c|c|c|}
\hline \multirow{3}{*}{$\begin{array}{l}\text { Vitamin A (ppm) } \\
\text { into RBDPOL }\end{array}$} & \multirow{3}{*}{$\begin{array}{l}\text { Storage } \\
\text { condition }\end{array}$} & \multicolumn{8}{|c|}{ MONTH } & \multirow{2}{*}{\multicolumn{3}{|c|}{6}} \\
\hline & & \multicolumn{2}{|l|}{$\mathbf{0}$} & \multicolumn{3}{|c|}{3} & \multicolumn{3}{|c|}{5} & & & \\
\hline & & Vit A IU g-1 & $\begin{array}{c}\text { PV } \\
\text { (meq/kg) }\end{array}$ & Vit A IU g-1 & $\begin{array}{c}\text { PV } \\
\text { (meq/kg) }\end{array}$ & $\begin{array}{c}\text { Vit A \% } \\
\text { Degraded }\end{array}$ & Vit A IU $g^{-1}$ & $\begin{array}{c}\text { PV } \\
\text { (meq/kg) }\end{array}$ & $\begin{array}{c}\text { Vit A \% } \\
\text { Degraded }\end{array}$ & Vit A IU g-1P & PV (meq/kg) & $\begin{array}{c}\text { Vit A \% } \\
\text { Degraded }\end{array}$ \\
\hline 70ppm $\left(\right.$ Light $\left.^{* *}\right)$ & & $70.5 \pm 0.36$ & $0.5 \pm 0.01$ & $62.9 \pm 0.45$ & $5.9 \pm 0.06$ & 11 & $60.9 \pm 0.11$ & $9.1 \pm 0.06$ & 14 & $60.3 \pm 0.03$ & $10.1 \pm 0.05$ & 15 \\
\hline 70ppm $\left(\right.$ Dark $\left.^{\#}\right)$ & & $70.5 \pm 0.36$ & $0.5 \pm 0.01$ & $66.3 \pm 0.45$ & $0.9 \pm 0.02$ & 6 & $63.8 \pm 0.11$ & $2.5 \pm 0.05$ & 9 & $63.6 \pm 0.20$ & $3.1 \pm 0.05$ & 10 \\
\hline 45ppm (Light) & $18-22 \mathrm{C}$ & $45.1 \pm 1.01$ & $0.5 \pm 0.02$ & $42.0 \pm 1.26$ & $5.6 \pm 0.02$ & 7 & $40.1 \pm 0.08$ & $10.6 \pm 0.06$ & 11 & $39.8 \pm 0.14$ & $11.3 \pm 0.06$ & 13 \\
\hline 45ppm (Dark) & & $45.1 \pm 1.01$ & $0.5 \pm 0.02$ & $42.5 \pm 0.01$ & $0.8 \pm 0.06$ & 6 & $40.4 \pm 0.37$ & $2.4 \pm 0.01$ & 10 & $39.9 \pm 0.03$ & $2.2 \pm 0.05$ & 13 \\
\hline 70ppm (Light) & & $70.5 \pm 0.36$ & $0.5 \pm 0.01$ & $62.5 \pm 1.16$ & $9.2 \pm 0.09$ & 11 & $58.3 \pm 0.06$ & $14.4 \pm 0.04$ & 17 & $57.6 \pm 0.16$ & $16.7 \pm 0.08$ & 19 \\
\hline 70ppm (Dark) & & $70.5 \pm 0.36$ & $0.5 \pm 0.01$ & $62.9 \pm 0.26$ & $9.2 \pm 0.12$ & 11 & $59.1 \pm 0.01$ & $11.5 \pm 0.06$ & 16 & $58.8 \pm 0.11$ & $15.7 \pm 0.06$ & 17 \\
\hline 45ppm (Light) & & $45.1 \pm 1.01$ & $0.5 \pm 0.02$ & $41.6 \pm 0.26$ & $8.51 \pm 0.13$ & 8 & $38.4 \pm 0.08$ & $15 \pm 0.02$ & 15 & $35.6 \pm 0.04$ & $18.3 \pm 0.01$ & 22 \\
\hline 45ppm (Dark) & & $45.1 \pm 1.01$ & $0.5 \pm 0.02$ & $41.9 \pm 0.75$ & $5.5 \pm 0.13$ & 7 & $39.0 \pm 0.02$ & $13.5 \pm 0.04$ & 14 & $38.6 \pm 0.12$ & $14.9 \pm 0.01$ & 16 \\
\hline
\end{tabular}

\# Dark $=<1$ Lux

$* *$ Light $=100$ to $150 \mathrm{~L}$ 
IV.

CONCLUSION

Overall, after 6 months of sample monitoring, the degradation of vitamin A was more than $10 \%$ at the lowest test temperature. This study confirms previous experimental findings [5], that fortification $45 \mathrm{IU}$ g- 1 in cooking oil is probably not enough to maintain the Vitamin A level at more than 20 IU g-1 during the entire shelf life.

The impact of temperature has a dramatic effect during storage. Samples kept at the cooler condition (18$22^{\circ} \mathrm{C}$ ), retained more vitamin A compared to samples kept at $31-33^{\circ} \mathrm{C}$, clearly showing heat treatment strongly influenced the degradation vitamin A [5]. Additionally, this work shows the advantage of keeping fortified oil away from high illuminance, thereby minimizing degradation of vitamin A. Without doubt, the handling and storing of fortified vegetable oil, before consumption could positively or negatively influence the final content of vitamin A [14]. Cooler storage, low illuminance or low UV light adsorbent packaging could minimize excessive loses of vitamin A during distribution and storage [12]. While effective mandatory fortification will benefit from suitable manufacturing and distribution [14, 29], our results suggest there are benefits in selecting suitable packaging materials, which are able to minimize illuminance from natural or artificial UV light $[15,5]$, together with the most optimal storage temperature in order to maximize vitamin A retention. Introduction of synthetic or natural antioxidants, together with the aforementioned mitigation methods, is another variant not yet explored and requires investigation.

We believe, this information is important to product developers and nutritionists, especially when fortified vegetable oils are frequently allocated by the United Nations World Food Programme to challenging locations with inadequate environmental controls. With this thought, it is worth noting that many tropical countries, locally consume minimally processed red palm oil as an important source of provitamin A because of its high $\beta$-carotene content [1].

\section{ACKNOWLEDGEMENTS}

We are grateful to the management of PT. SMART Tbk. (Golden Agri-Resources), for supporting the publication of this research paper.

\section{REFERENCES}

[1]. Willett, W. Rocktröm, J. Loken, B. et al. (2019). Food in the Anthropocene: the EAT-Lancet Commission on healthy diets from sustainable food systems. http://dx.doi.org/10.1016/S01406736(18)31788-4

[2]. Global Alliance for Improved Nutrition (GAIN) (2010). Fortification of vegetable oil in Indonesia. www.gainhealth.org/knowledgecentre/project/fortificationvegetable-oil-indonesia.

[3]. Riskesdas (Riset kesehatan dasar) (2010). National report on basic health research by national institute of health research and development. Indonesia: Ministry of Health.

[4]. Soekirman, Soekarjo, D., Martianto, D., Laillou, A. \& Moenchpfanner, R. (2012). Fortification of Indonesian unbranded vegetable oil: public - private initiative, from pilot to large scale. Food and Nutrition Bulletin, 33, S301-S302.

[5]. Silalahi, D. K., Yuliyanti, D. , da Silva, M. , Christianti, I. , Mulyono, K. and Wassell, P. (2017), The stability of vitamin A in fortified palm olein during extended storage and thermal treatment. Int J Food Sci Technol, 52: 1869-1877. doi:10.1111/ijfs.13462.

[6]. FAO/WHO (2004). Vitamin and mineral requirements in human nutrition, 2nd ed. Report of a joint FAO/WHO expert consultation,
Bangkok. Gwanfogbe, P.N., Chambers, E.I., Martin, G., Fotso, M., \& Smith.

[7]. FAO/WHO (2006). Guidelines on food fortification with micronutrients. Allen, L, Benoist, Bruno de, Dary, O., et al.

[8]. Atwood, S.G., Sanghvi, T.G., Sharma, V. \& Carolan, N. (1995). Stability of vitamin A in fortified vegetable oil and corn soy blend used in child feeding programs in India. Journal of Food Composition and Analysis, 8, 32-44.

[9]. Farhang, B and Nikoopur, H. (2004) the effect of light and temperature on stability of vitamin A in the fortified vegetable oils (hydrogenated and nonhydrogenated). Asia pacific journal of clinical nutrition 2004.

[10]. Combs Jr, G.F. (2008). The Vitamins: Fundamental aspect in nutrition and health. Elsevier.inc. $3^{\text {rd }}$ ed.

[11]. Hariyadi, P. (2009). Technical aspects of oil fortification with vitamin A. Industrial Role of Cooking Oil Fortification with Vitamin A in Indonesia. Southeast Asian Food \& Agricultural Science \& Technology (SEAFAST) Center, Bogor Agricultural University, BOGOR, Indonesia. April 21, 2009.

[12]. Andarwulan, N., Gitapratiwi, D., Laillou, A. et al. (2014). Quality of vegetable oil prior to fortification is an important criteria to achieve a health impact. Nutrients, 6, 5051-5060.

[13]. Siracusa, V. (2012). Food packaging permeability behaviour: a report International Journal of Polymer Science, 1-11.

[14]. Dwyer, J.T., Wiemer, K.L., Dary, O. et al. (2015). Fortification and health: challenges and opportunities. Advances in Nutrition, 6, 124 131. https://doi.org/10.3945/an.114.007443

[15]. Barrett, A. H., Richardson, M. J., Froio, D. F., O’Connor, L. F., Anderson, D. J. and Ndou, T. V. (2018). Long-Term Vitamin Stabilization in Low Moisture Products for NASA: Techniques and Three-Year Vitamin Retention, Sensory, and Texture Results. Journal of Food Science, 83: 2183-2190. doi:10.1111/1750 3841.14218

[16]. Carlotti, M.E., Rossatto, V., Gallarate, M., et al. (2004). Vitamin A palmitate photostability and stability overtime. J. Cosmet. Sci., 55 , 233-252.

[17]. Andarwulan, N., Muhammad, G.N., Agista, A.Z. et al. (2016). Photo oxidation stability of palm oil fortified by red palm oil. Journal Teknol. and Food Industry, 27, 31-39. ISSN: 1979-7788.

[18]. Hemery, Y.M., Fontan, L., Moench-Pfanner, R. et al. (2015). Influence of light exposure and oxidative status on the stability of vitamins A and D3 during the storage of fortified soybean oil. Food Chemistry, 184, 90-98.

[19]. Pignitter, M., Hernler, N., Zaunschirm, M. et al. (2016). Evaluation of palm oil as a suitable vegetable oil for vitamin a fortification programs. Nutrients, 8, 378. doi:10.3390/nu8060378.

[20]. Howell, R., Rosario, L., Bula, A. (1997) Effects of indoor relative humidity on refrigerated display case performance. In: Proceedings of CLIMA 2000, Brussels, Belgium.

[21]. BMKG (Badan Meteorolgi, Klimatologi, dan Geofisika) (2017) Minimum and Maximum temperature Tanjung Priok Jakarta at 19812010. http://web.meteo.bmkg.go.id/id/iklim (5 January 2018)

[22]. Japanese Industrial Standard (2006) JIS C 1609-1 Illuminance meters Part 1: General measuring instruments. ICS Code (Optical measuring instruments): 17.180.30. Pub: Japanese Standards Association.

[23]. CIBSE (2012). Lighting Guide 01: The Industrial Environment LG01. Chartered Institute of Building Service Engineers.

[24]. Bagriansky, J. \& Ranum, P. (1998). Vitamin A fortification of PL 480 vegetable oil. US Agency for International Development,1-29.

[25]. Association of Analytical Chemists (2011). AOAC official method 2001.13. Vitamin A (retinol) in foods, liquid chromatography, 19th ed., Chapter 45.1 .

[26]. Birch, K. (2003). Estimating uncertainties in testing, measurement good practice guide No. 36. British Measurement and Testing Association. ISSN 1368-6550.

[27]. Pignitter, M., Dumhart, B., Gartner, S. et al. (2014a). Vitamin A is rapidly degraded in retinyl palmitate-fortified soybean oil stored under household conditions. Journal of Agricultural and Food Chemistry, 62, 7559-7566.

[28]. Pignitter, M., Stolze, K., Gartner, S. et al. (2014b). Cold fluorescent light as major inducer of lipid oxidation in soybean oil stored at household conditions for eight weeks. Journal of Agricultural and Food Chemistry, 62, 2297-2305.

[29]. Osendarp, S.J.M., Martinez, H., Garrett, G.S et al. (2018) LargeScale Food Fortification and Biofortification in Low- and MiddleIncome Countries: A Review of Programs, Trends, Challenges, and Evidence Gaps. Food and Nutrition Bulletin. 39 (2) pp. 315-331 https://doi.org/10.1177/0379572118774229 